\title{
An Analysis of the Types and Pattern of uses and Control Rights over Multiple uses of Tank Irrigation System in South India
}

\author{
C. Karthikeyan ${ }^{1}$ and P.S. Swathi lekshmi ${ }^{2}$ \\ ${ }^{1}$ Department of Agricultural Extension and Rural Sociology, Tamil Nadu Agricultural University Coimbatore, \\ Coimbatore-641 0003, Tamil Nadu \\ ${ }^{2}$ Agricultural Extension, Central Marine Fisheries Research Institute, Vizhinjam-692521, \\ Thiruvananthapuram, Kerala
}

Email: swathi.lekshmi263@gmail.com

\begin{abstract}
The study examines the property rights related to conservation and sustainable management of tank irrigation systems in South India. Tanks are a symbol of social and cultural entity closely woven in to the livelihood of the common man as it serves a multitude of functions such as irrigation, livestock, fisheries, duck rearing and domestic water supply as well. A study of the types, pattern of uses and control rights over Tank irrigation system is important for the sustainable management and conservation of tank irrigation systems. The research was carried out during 2007-09 by selecting one system tank and 31 non-system tanks drawn from eight tank-chains present in two tank intensive districts (Villupuram and Kancheepuram) of Tamil Nadu state, India. Case study was conducted in the system tank to collect data using Participatory Rural Appraisal PRA method. From each of the 31 non-system tanks, a random sample of key informants ranging 12 to 15 users (totalling 400) who depended on various tank resources was drawn from the 31 non-system tanks for data collection through PRA. The results on the performance of tanks in the light of its multiple uses (or physical resource use efficiency) indicated that agricultural use dominated in terms of its use share performance in absolute terms. Uses such as domestic, Live Stock Drinking (LSD) and fishery performed better next to agriculture. The intensity of property rights in terms of access, withdrawal, management, exclusion and alienation, for the five uses of tank namely irrigation, social forestry, silt, fishing and bund trees were found to be exercised by various groups of users at lower level in most of the tanks. The uses namely domestic, duck rearing, hard grass collection, LSD and brick making were found to be enjoyed by the users at higher level of intensity of PR by the respective user group. The intensity of property rights seems to be high for those uses with less number of users than for the uses like agriculture, fishery, Social Forestry, silt and bund trees wherein there were too many users with competition among them to enjoy the benefits of the resource. Hence existence of a strong users' institution would facilitate the users to enjoy the property rights over the tank resources at a higher level in an appropriate manner.
\end{abstract}

Key words: Customary rights, group rights, individual rights, property rights, system and non system tanks and tank irrigation

\section{Introduction}

A tank is a simple earthen banked rainwater harvesting and storage structure, designed by the early settlers using their indigenous wisdom and constructed with the generous support of native rulers and chieftains over the past several centuries. Surprisingly these earthen structures have withstood the test of time and survived over many centuries. They are simple technological innovations developed by those people to accommodate their primary needs and adapted to the distinctive Indian climate-intense monsoons followed by protracted droughts. In India, an irrigation tank is a small reservoir constructed across the slope of a valley to catch and store water. Irrigation tanks have existed in India from time immemorial, and have been an important source of irrigation water, especially in Southern India where they supply water for more than one-third of the total irrigated area in Andhra Pradesh, Karnataka and Tamil Nadu states. In rural areas of southern India, a 'tank' is typically used for multiple purposes, such as irrigation, livestock, fisheries, duck rearing, brick making, silt, and domestic water supply as well. To maximize the benefits from the different uses, it is important to see how these uses/user groups interact. Several studies reported that the tank irrigation in India declined over years due to various reasons such as changes in rainfall pattern, disintegration of traditional water users' institutions that were managing the tanks, poor maintenance and management, conflicts among farmers in sharing of water (Janakarajan, 1996; Palanisami et al., 1997; Raj and Sundaresan, 2005). However, the decline in tank irrigation could also be due to unsustainable water use pattern or existing weak property rights condition due to poor management of the tanks and this issue needs to be explored. Disincentives, like inappropriate water pricing systems can induce overuse or wastage of water thus leading to the unsustainable water use from irrigation systems. Inefficient irrigation damages the performance of irrigation projects too (FAO, 2005). It was reported by (FAO, 2000) that, establishing an effective water right institution will play an important role in the rational and sustainable management of water resources. In many parts of the world both the free distribution and under pricing of water have caused serious misuse of the resource (World Bank, 1993).

The issue has to be examined in the light of the pattern of property rights enjoyed by the people over the tank resources 
and how these rights were regulated by various institutions. Information on how a tank performs from multiple uses perspective is also needed to make decisions regarding selection of tanks for rehabilitation programs which is considered to be one of the strategies towards sustainable management of tanks. Sustainability of tank system is affected by problems at the following three levels namely, tank, users, and institutions. It is therefore related to how well these problems are addressed. Against this background, it was decided to analyse the types and pattern of use and control rights over the multiple uses of tank system.

\section{Research methodology}

\section{Selection of tanks}

Tamil Nadu state has 39,000 tanks which includes both system (15\%) and non-system tanks (85\%). The study is proposed to cover both types of tank namely, system and non-system tanks present in the two tank-intensive locale of Villupuram and Kanchipuram districts of Tamil Nadu state. The tank-intensive districts are those where tank irrigated area is more than onefourth of the total irrigated area by all sources. As this study focus on the multiple uses and user groups of a tank it was decided to consider the presence of maximum number of tank uses and maximum number of users who depended on tanks as the criteria to select a sample of 'system' and 'non-system' type of tanks for the study. To identify the maximum number of users of a tank, the total number of farmers in the command area of a tank was taken as the proxy. Hence one system tank (Kalpattu) managed by the WRO (Water Resources Organisation) was selected from Villupuram district. This is a representative system tank and comparable to other system tanks in the state in terms of its hydrological features, presence of tank uses and institutional structure that governed the tank management. Case study was done in the light of the objectives of the research to collect data from this system tank.

To select the sample of non-system tanks, the tank-chain approach was followed to study the objectives in a more systematic and realistic way, since most of the tanks in the state falls in chains and not in isolation. The location of tanks in a chain might also have an effect on the presence of number of uses and tank performance. Hence sample tanks were drawn from chains covering both head and tail end. Considering the manpower and time limitations four tank-chains were selected from each district thus making a total of eight tankchains. From each tank-chain, four tanks were selected which included two from head end and two located at tail end of the tank-chain. Considering the presence of maximum number of tank uses and maximum number of users who depended on tanks as the criteria, a sample of 32 non-system tanks was drawn randomly from the selected tank-chains of the two districts. However based on the completeness and precision of data collected, 31 tanks were considered for data analysis using SPSS package.
These selected non-system tanks were post stratified based on the management authority as WRO and PU (Panchayat Union) tanks. Accordingly, there were $26 \mathrm{WRO}$ and 5 PU tanks selected for this study. Studying the influence of type of tank according to management authority and comparisons between the tank types are beyond the scope of this study. Hence research was continued with this sample of 31 tanks which is quiet sufficient for a study of this nature which concentrated to collect most of the required data from the sample of tank users.

\section{Selection of respondents (tank users)}

Data was gathered from a group of 12-15 tank users drawn from each of the selected tanks comprising agricultural, nonagricultural and domestic users of the tanks. In selecting the group of respondents' priority was given to include key informants for every use such as: older farmers/farm women, village head man, WUA (Water Users Association) office bearers, SHG (Self Help Group) women member, Village Panchayat leader, caste group representative, silt users, brick makers, domestic users, tree users, fish right holders and livestock farmers.

\section{Methods of data collection}

Participatory Rural Appraisal (PRA) was conducted in all the 31 selected tank villages with the group of selected key informants. Transect walk, rapport building, preference ranking, group discussion, triangulation, were the techniques of PRA handled to gather data regarding the key research questions on analysis of the control rights over multiple uses of tank irrigation. A semistructured interview schedule covering questions on the control rights and intensity of property rights over tank resources, extent of the types of property resources over tank resources and use wise intensity of property rights over tank resources were administered to a group of respondents in each of the selected tanks to gather the data for the study.

\section{Operationalisation and measurement for the quantification of the variables of this study is detailed as follows:}

\section{Property rights}

Property was defined as a benefit (or income) stream from any tangible or intangible objects and (or) circumstances and property rights (PR) in a tank system refers to the claim over the benefit streams that are recognized and respected by people (Singh, 1994). In general PR to natural resources can be conceived of as a hierarchy ranging from limited short term rights such as access and withdrawal rights to extensive, long term rights to the benefit stream as rights to management, exclusion and alienation (Schlager and Ostrom, 1992). In the context of a tank system this bundle of property rights are operationalised as follows:

Access (A) : The right to enter a defined property of a tank system and enjoy non consumptive benefits for a specific purpose. eg: Duck rearing, fish rearing.

Withdrawal (W) : The right to obtain the benefits from the property of a tank system by taking out/utilising some portion of it. eg: Irrigation. 
Management (M) : The right to regulate use patterns, and transform the resource of a tank system, potentially altering the stream of benefits from that resource. eg: Water control and sharing by the management authorities like Water Resources Organisation. (WRO)

Exclusion (E) : The right to exclude / keep out the non-right holders from the property of a tank system and to decide how the use rights can be transferred. eg: Keeping out the encroachers, farmers from non-command area to use water.

Alienation (A) : The rights to sell, lease (or) bequest control rights to the resource of a tank system. eg: Fishing, tree harvesting, removal of silt etc.

Access and withdrawal are considered as use rights, while management, exclusion and alienation are control rightsenforcing authority over the resource.

Depending upon the enjoyer/rights holder, a right may be enjoyed either by an individual or a group. Traditionally in South India there have been both individual and group rights over tank resources. PR in a tank system may be quantified in terms of Individual Rights (IR) (for example, fishing) and Group Rights (GR) (for example, irrigation) considering the right holder in the light of a bundle of rights namely, access, withdrawal, management, exclusion and alienation rights. The degree of enjoyment of rights by either individual or a group varied across tanks depending on the specificity and enforceability of rights over the tank benefit streams. Accordingly, the PR was classified as high, medium and low giving scores of 5, 3 and 1, respectively for individual bearer and 10, 6 and 2 scores can be given if the $\mathrm{PR}$ is enjoyed by a group. The rationale for giving higher range of scores for group rights is that "creation of private PR in common property resources may result in socially undesirable effects such as substantial social inequality and conflict if the allocation of rights is unequal (or) if the social obligations of the new property holders are not clearly defined and enforced. Hence the PR of a tank system was quantified as follows.

\section{Scoring pattern of PR}

\begin{tabular}{lcc}
\hline Level of property rights & \multicolumn{2}{c}{ PR score } \\
\hline & $\begin{array}{c}\text { Individual } \\
\text { rights (IR) }\end{array}$ & $\begin{array}{c}\text { Group rights } \\
\text { (GR) }\end{array}$ \\
\hline High (Right well specified and enforced rate) & 5 & 10 \\
$\begin{array}{l}\text { Medium (Right well specified but not enforced } \\
\text { perfectly) }\end{array}$ & 3 & 6 \\
Low (Right not specified and not enforced) & 1 & 2 \\
\hline
\end{tabular}

The PR score for a tank system was calculated by summing the scores for IR and GR for the bundle of rights namely Access, Withdrawal, Management, Exclusion and alienation related to ' $n$ ' number of the multiple uses observed in a tank. Hence the PR score for each of the selected Panchayat Union (PU) and Water Resources Organisation (WRO) tanks was calculated. Based on the mean PR score, the intensity of PR over multiple uses of tank system was calculated and categorized a slow (below the mean value) and high level (above the mean value) for the PU and WRO tanks separately. The frequency distribution of the PU \& WRO tanks coming under each category was calculated and expressed in percentage.

\section{Findings and discussion}

There existed four types of rights related to tank resources. They were (i) Natural (Fundamental/basic) right (or) a right granted in law (ii) Customary right (or) a new right accepted/granted by the state law (iii) Individual or group right and (iv) Riparian right. In this study focus has been given to analyze the pattern of rights over tank water and tank based resources. It is also equally important to know the basis of water rights prevailing in the contemporary situation.

A semi structured interview schedule covering questions on the following aspects namely, customary rights enjoyed by the tank users, the intensity and pattern of use and control rights enjoyed by the tank users, women Vs water rights, probability of occurrence of uses in a tank for the past 10 years, preference to various uses of a tank and preference ranking of the tank uses, roles of the informal or formal WUA, competition and conflicts among and between various user groups and constraints felt by the tank users for sustainable management of the tanks was developed and administered to the group of respondents in each of the selected tanks to gather the data for the study.

\section{Customary rights to share irrigation water}

The findings about the customary rights to share tank water for irrigation use that prevailed in the selected tanks during season and off-season periods is presented in Table 1. The tank water was shared by the command area farmers based on certain norms which are implemented by the WUA and these norms were being followed by the farmers over years. These are unwritten rules to regulate the irrigation water use of a tank system mostly executed by the President of the Water Users Association (WUA) called locally as Nattamai/Neermaniyam/Neermaniakaran. The study revealed that, there existed customary rights in all the tanks to share the water among the command area farmers. However due to growth of wells in the tank command, inadequate supply of water to the tanks and poor maintenance these unwritten rules were not followed strictly in almost $50 \%$ of the tanks. The norms existed in terms of the sequence of irrigation, time of irrigation, preference to certain users in providing irrigation and order in which the sluice was opened for irrigation.

Table 1 : Pattern of customary rights for sharing irrigation water

\begin{tabular}{lcc}
\hline Norms followed & \multicolumn{2}{c}{ Tanks $(\mathbf{n}=\mathbf{3 1})$} \\
\cline { 2 - 3 } & Number & Per cent \\
\hline - Water distribution sequence (during season) & 15 & 48.39 \\
Priority to head end & 7 & 22.58 \\
Priority to tail end & 6 & 19.35 \\
First come first served basis & 2 & 6.45 \\
Priority to transplanted fields & 1 & 3.22 \\
Priority to temple lands & &
\end{tabular}

- Water distribution sequence (during off-season) 


\begin{tabular}{lcc} 
Priority to head end, irrigation to fixed area/ farmer & 10 & 32.26 \\
First come first served basis & 8 & 25.80 \\
Priority to dry fields, fixed area/ farmer & 8 & 25.80 \\
Priority to head end, irrigation fixed time/ac & 5 & 16.13 \\
- Time of irrigation & & \\
Day time only & 14 & 45.16 \\
Rotational basis (Villages) & 13 & 14.93 \\
Round the clock & 4 & 12.90 \\
- Preference to users & & \\
Widow (farm women) & 3 & 9.68 \\
Old aged farmers & 3 & 9.68 \\
- Sluice first & & \\
Upper sluice first & 17 & 54.83 \\
All at one time & 9 & 29.03 \\
Lower sluice first & 5 & 16.13 \\
\hline
\end{tabular}

It could be inferred from Table 1 that as far as the sequence of water distribution during season was concerned, about $48.39 \%$ of the tanks adopted the option of giving priority to those farmers who had their lands at the head end to irrigate first followed by the rest of the command area. About one-third of the tanks gave priority to the tail end farmers first to irrigate their fields followed by others. Likewise the other norms followed to distribute irrigation water were, first come first served (19.35\%), priority to those farmers who had completed transplantation of paddy in their field $(6.45 \%)$ and in one tank priority was given to irrigate the lands that belong to the temple that existed in the village.

An overview of the traditional norms followed during scarcity or off season period revealed that more than three-fourth of the tanks had adopted specific norms to share and distribute water among the farmers of the tank command through irrigation functionaries. In most of the tanks these norms were enforced by the informal water users' association comprising of a group of elderly farmers in the tank command. In is interesting to note that two popular principles were followed to share water proportionate to the land area owned by the farmers in the tank command. They were (i) fixing limited area under tank irrigation for each farmer in the ayacut and (ii) fixing limited time of irrigation per acre of land owned by an individual farmer. The fixation of limited area per farmer was conceived as either $50 \%$ or less of the land area owned by an individual farmer in the ayacut. For example, if a farmer owned one acre he will be asked to cultivate/irrigate 50 cents only. The fixation of limited time per acre of land in the command area was decided depending upon the quantity of water filled in the tank, quantity of discharge of water from the sluice, and number of sluices to be opened simultaneously. Depending on these factors the time fixed per acre varies across tanks. These norms were adhered to by the irrigation functionary (IF) at the time of distributing water to the farmers. Meinzen-Dick and Bakker (2000) had also reported prevalence of the customary laws and local norms in defining the irrigation use of Krindioya irrigation system in Sri Lanka.

Results revealed that one third of the tanks adopted the method of giving priority to head end following fixed area of irrigation per farmer in the command area. 'First come first serve' basis was observed in about one-fifth of the tanks at the time of scarcity. Similar results were observed in PU and WRO tanks. Other patterns of sharing water observed in both PU \& WRO tanks included priority to dry field and sharing based on fixed area/ farmer basis $(25.8 \%$ each). The traditional norm of giving priority to head end following fixed time/acre was observed in $16.13 \%$ of the tanks.

Norms were also framed and implemented for the timing of irrigation done in the tanks. Nearly $50 \%$ of the tanks appointed irrigation functionary commonly called as 'Kambakaran' to distribute and regulate the water flow from the tank and to the farmers' fields. In about $45.16 \%$ of the tanks, day time irrigation i.e. letting the water to flow from the tank to the fields during 6 a.m. to 6 p.m. only. About $42 \%$ of the tanks adopted rotational pattern to irrigate the command area. This is normally adopted whenever the command area of a tank had more than one village or even the rotation was done between head and tail end of the tank command. The first rotation was from 6 a.m. to 6 p.m. particularly allotted for the head end or to the village in which the tank was located physically. The second rotation was adopted from 6 p.m. to 6 a.m. normally given to the tail end area or to the command area that existed in other villages. Nearly $13 \%$ of the tanks adopted round the clock irrigation till the entire command area was completely irrigated.

It was interesting to note that in nearly one tenth of the tanks, the WUA gave its first preference to irrigate the fields owned by those farm women who were destitute widows and to these aged farmers who were helpless in their family. This preference was given on humanitarian basis by the WUA.

There existed norms in the order in which opening of the sluice was observed. Normally there will be sluices which let the water out of the tank positioned according to the slope of the land. Most of the tanks (54.83\%) opened the upper sluice first followed by its lower ones while about $29 \%$ of the tanks adopted no priority in opening the sluice rather they just opened all the sluices at one time to irrigate the command area in all the directions. This happened in two situations. First wherever the farmers expressed noncooperation to follow the norms in opening of the sluices and secondly when the sluices were out of its function. About $16 \%$ of the tanks had the priority to open the lower sluice of the tank for irrigation.

Water distribution to individual farmers in the ayacut during scarcity was done by Irrigation Functionary (IF) invariably in all these tanks for which the payment to IF was made in kind. Water distribution in most of the tanks during normal period was done by farmers themselves. But for giving priority for the release of water for irrigation, no other norms were followed during scarcity period. These norms were adopted and enforced in a strict manner during scarcity period in olden days. But now these norms were not given due respect by a considerable number of farmers in the tank command. This might be due to decrease in the importance given by farmers for tank irrigation. 


\section{Possible reasons elicited for this was as follows:}

1. Fragmentation of land leading to too many land owners and lack of co-operation among farmers to use the common property resources judiciously in a sustainable manner.

2. Lack of assured water supply to and from the tank for the farmers.

3. More efforts (in terms of labor) needed for water augmentation and use of tank water.

4. Lack of interest for villagers to take up public works like Kudimaramath/channel cleaning/desilting etc. (users participatory maintenance of tanks) to use tank water.

5. Only single crop could be raised from tank water and hence farmers were not willing to pay for the irrigation functionary (commonly called as 'thoti')

6. The policy of free electricity for agriculture in the state encouraged even medium and small farmers to go for ground water use through bore wells. This had increased the number of wells in the tank command.

7. Preference of the farmers towards use of individual water resource (wells) over common resource (tank)

8. Inadequate repair and maintenance of tanks by management authorities due to poor fund allocations.

\section{Customary rights to share fishery benefits from tank}

Fish yield from tank water is one of the multiple uses of tank which was largely enjoyed by the villagers. Considerable yield of fish would be available in the tank during season or normal period, which would be relatively less or absent during water scarcity or offseason period. The pattern of sharing the fish depended on the nature of property right enjoyed by the users of a tank and the availability of fishes in the tank. The results on the customary rights to share the fishery benefits from tanks are presented in Table 2.

Table 2 : Pattern of customary rights to share fish benefits from tanks

\begin{tabular}{lcc}
\hline Norms followed & \multicolumn{2}{c}{ Tanks (n= 31) } \\
\cline { 2 - 3 } & Numbers & Percent \\
\hline Reauction by IWUA & 10 & 32.26 \\
Reauction by WUA & 9 & 29.03 \\
Needy people are enjoyers & 5 & 16.13 \\
'Kollai Veesuthal' & 3 & 9.68 \\
Equal share/ family by paying equal dividend & 2 & 6.45 \\
Auction/ sharing fish by right holders & 1 & 3.22 \\
Auction by FCS (Fisheries co-operative society) & 1 & 3.22 \\
\hline
\end{tabular}

There existed seven patterns of sharing the fish yield harvested from tanks. Among these, the most popular pattern of sharing was re-auctioning of the fish benefit by the users' association $(61.29 \%)$. As regards re-auction by Informal Water Users Association/ Water Users Association (IWUA/WUA), the fishing rights were primarily alienated by the panchayat union officials and revenue officials in the case of PU and WRO tanks respectively through open auction. The IWUA/WUA takes the bid and again transfers the fishing right to an individual through the process of open auction. The amount earned through re-auction of fish was utilized for temple festivals and for developmental works including tank maintenance.

Under the 'needy people are enjoyers' system of sharing, users who wish to collect fish were allowed to enjoy it freely. This norm was followed due to low level of yield harvested in the tank continuously over years. This may also be attributed to the transfer of land ownership coupled with fragmentation of land. In general, the fishing rights were enjoyed by the land owners in the command area. At the time of land trading, sellers retain the fishing right with them. They enjoyed the fishing rights but due to their absence in the ayacut, the rights were not secured. Hence enforcement of the fishing right was not established strictly and accordingly the fishing rights changed over years and the norms were also not given due respect by the users which results in the practice of allowing all those who need to enjoy the use. Open access to the resource resulted when the boundaries were not clear. This pattern of sharing was observed in $16.13 \%$ tanks.

Other sharing pattern observed in one-tenth of the tanks includes 'Kollai Veesuthal' conducted by the IWUA. Here the IWUA pay the 'meenpasi' (Fishing tax) amount to the panchayat and organised the practice of 'Kollai Veesuthal' in the tank to enjoy the fish yield. The IWUA decides the date and time of free catching of fish in the tank and makes an announcement to the villagers. At that time all the villagers including willing persons from neighboring villages also participated in 'Kollai Veesuthal'. The president of IWUA gives the green signal to harvest and share the fish and following this all the participants took an equal and fixed share of fish from the tank without any payment.

In some tanks the fishing rights were owned by a group of members belonging to a family for the simple reason that in olden days the entire ayacut was owned by them. While trading the land rights, the fishing rights were retained with them. Hence these small group of farmers only enjoyed the fishing right. They paid the 'meenpasi' (permanent fisheries rent) amount to the panchayat and alienated the fishing rights through auction conducted by them. This pattern was observed in $3.22 \%$ of tanks.

In few tanks $(6.45 \%)$ the payment of 'meenpasi' was paid by the IWUA and collected meagre amounts say ₹ 2 /family in the village towards enjoyment of their fish share from the tank. The fish harvested from the tank was divided into a number of equal shares and given to all those interested families in the village. The amount collected from the village households were spent by the IWUA for celebrating temple festivals and to attend the developmental works in the village including tank maintenance.

As a unique case the fishing rights were owned by a small group of farmers belonging to a family. Whatever the yield obtained was shared equally by the right holders without conducting auction. The reason being that, since long period, entire ayacut area was owned by the family and during land trading they had 
retained the fishing rights with them. Hence the fishing rights in the tank were enjoyed by the family members only.

The fishery activity in few WRO tanks was controlled by the fisheries department of the state. In these tanks the fisheries department had leased the fishing rights to Fisheries Cooperative Society (FCS) for a period of three years. Hence during this period the fishing rights were enjoyed by the FCS only. Such pattern was observed in a single case. At the time of water scarcity or off season period, fish availability in the tank was scarce or absent. Accordingly the pattern of rights enjoyed by the fish users also gets changed. Majority of the PU and WRO tanks adopted the policy of 'wanters can enjoy' the fish in the tank. During scarcity period, it is not worth to organise the users collectively to enforce rights. The obvious pattern of sharing fish namely 'Kollai Veesuthal' by IWUA were observed. A fish right gets changed during scarcity period due to less or absence of fish availability in the tank. In majority of the tanks the rights to enjoy fish from the tank was not enforced due to the limited availability of fish in the tank and due to the prevalence of low extent of PR over fish resource. But still the tank users give due importance to harvest and enjoy the fish. Hence the findings highlight the need for fisheries development activity in tanks so as to sustain the use further in a larger way.

The PR of a benefit stream in the tank system involved six types of rights namely right to access, withdrawal, management, control, exclusion and alienation. An analysis on the bundle of rights related to the multiple uses of the tank revealed that PR were defined and enforced at higher level (48.39\%) and lower level (51.61\%) equally in the tanks. When the PR over the multiple uses of a tank is well defined and enforced then it can be said that there existed complete PR which would facilitate the users to enjoy the benefit stream perfectly. Such condition was observed in $48.39 \%$ of the tanks only. Hence the PR over benefit streams of tank system needs to be strengthened in future. The intensity of PR in terms of access, withdrawal, management, exclusion and alienation, for the five uses of tank namely irrigation, social forestry, silt, fishing and bund trees were found to be exercised by various groups of users at lower level in most of the tanks. In these tanks, the PR was found to be enforced at a lower level by means of both legal and customary rights. The uses namely domestic, duck rearing, hard grass collection, LS drinking and brick making were found to be enjoyed by the users at higher level of intensity of PR by the respective user group. Study reveals that common and reliable uses which are capable of generating revenue were observed to possess the PR relatively at lower level as compared to uses that are complementary to common uses and which are relatively less (or) not capable of generating revenue from the respective users. In other words the intensity of PR seems to be high for those uses with less number of users than for the uses like agriculture, fishery, SF, silt and bund trees wherein there were too many users with competition among them to enjoy the benefits of the resource. It is inferred that the level of PR may have been some influence on the level of collective efforts taken by the villagers either through formal or informal organizations and such efforts or collective action have several impacts on tank management.

\section{Intensity of property rights over tank resources}

The PR score for a tank system was calculated by summing the scores for IR and GR for the bundle of rights namely Access, Withdrawal, Management, Exclusion and Alienation related to ' $n$ ' number of the multiple uses observed in the tank. Hence the PR score for each of the selected PU and WRO tanks was calculated. Based on the mean PR score, the intensity of PR over multiple uses of tank system was calculated and categorized as low and high level for the PU and WRO tanks separately. The frequency distribution of the PU \& WRO tanks coming under each category was calculated and expressed in percentage. The results are presented in Table 3 . The results reveal that the intensity of PR over the multiple uses of the tank was found to be at low (51.61\%) and high (48.39\%) levels with almost an equal proportion. Almost similar trend was observed in WRO tanks with higher proportion of tanks $(53.85 \%)$ coming under high intensity PR category. This implies that the PR over the benefit streams were defined and enforced at higher level in WRO tanks as compared to PU tanks. This is because of the availability of tank resources which makes the tank users to enjoy the benefits. The villagers' dependency on WRO tanks for irrigation, fishing, social forestry, silt collection, brick making etc. were found to be relatively higher than the PU tank and hence the expression of PR was found to be explicit in WRO than PU tanks. Hence considering the overall analysis, it can be inferred that the bundle of rights related to the multiple uses of the tank seems to be defined and enforced at higher level and lower level equally in half of the sample tanks. When the PR over the natural resources is well defined and enforced then it can be said that there existed complete PR which would facilitate the users to enjoy the benefit stream perfectly (Schlager and Ostrum, 1992). The results reveal that such condition was observed in 48.39 per cent of the tanks only. Hence the PR over benefit streams of tank system needs to be strengthened in future.

\section{Table 3 : Intensity of PR over multiple uses in tanks}

\begin{tabular}{lllllll}
\hline Tanks & \multicolumn{2}{l}{ PU } & tank $(\mathbf{n}=\mathbf{5})$ & \multicolumn{2}{c}{ WRO tank $(\mathbf{n}=\mathbf{2 6})$} & \multicolumn{2}{l}{ Total $(\mathbf{n}=\mathbf{3 1})$} \\
\cline { 2 - 7 } & $\mathbf{n}$ & $\mathbf{\%}$ & $\mathbf{n}$ & $\mathbf{\%}$ & $\mathbf{n}$ & $\mathbf{\%}$ \\
\hline Low & 4 & 80.00 & 12 & 46.15 & 16 & 51.61 \\
High & 1 & 20.00 & 14 & 53.85 & 15 & 48.39 \\
\hline
\end{tabular}

\section{Extent of the types of PR over tank resources}

As mentioned earlier, the PR of a benefit stream in the tank system involves six types of rights namely right to access, withdrawal, management, control, exclusion and alienation. An analysis was done to understand which type of PR was well specified and enforced and to what extent for the multiple uses in the selected PU and WRO tanks. For this purpose the extent of PR score for 'access' right related to all the multiple uses observed in each of the PU and WRO tanks were summed 
respectively and mean value was calculated. Based on the mean value the extent of access right prevailing over the multiple uses of tank system was categorized as low and high. Same procedure was adopted to find out the extent of withdrawal, management, control, exclusion and alienation rights for the tank benefits. The results are presented in Table 4.

Table 4 : Extent of the types of PR over the multiple uses of the tank

Unit: Percent of tanks

\begin{tabular}{ccccccc}
\hline \begin{tabular}{c} 
Tank \\
\multicolumn{6}{c}{$\begin{array}{c}\text { Extent } \\
\text { of PR }\end{array}$}
\end{tabular} & Access & Withdrawal & Management Exclusion & Alienation \\
\hline WRO Low & 36.36 & 36.36 & 36.36 & 36.36 & 54.55 \\
& High & 63.64 & 63.64 & 63.64 & 63.64 & 45.45 \\
PU & Low & 63.64 & 63.64 & 72.73 & 72.73 & 63.64 \\
& High & 36.36 & 36.36 & 27.27 & 27.27 & 36.36 \\
\multirow{2}{*}{ Total } & Low & 36.36 & 45.45 & 36.36 & 36.36 & 54.55 \\
& High & 63.64 & 54.55 & 63.64 & 63.64 & 45.45 \\
\hline
\end{tabular}

This result indicate that almost all the six types of PR over the multi-uses of tanks were well specified and enforced uniformly at higher level in most of the WRO tanks as compared to the PU tanks. In the WRO tanks the extent of access, withdrawal, management and exclusion rights were found to prevail at higher level in 63.64 per cent of the tanks. In majority of the PU tanks, all the five types of rights were found to be at low level.

The pooled analysis revealed that in most of the tanks the extent of access, withdrawal, management and exclusion rights over the tank resources were observed to be well defined and enforced at a higher level. This implies that the types of PR over the multi uses of the tank system cannot be viewed as a separate entity i.e., one type of right leads to the possession of other type of right. For e.g. an individual can have withdrawal rights on a property only when he has the right to access the resource. The possession of management right provides the ability to define withdrawal rights. Hence the access, withdrawal and management rights over the enjoyment of the multi-uses of the tank were interlinked with each other and hence the extent of these three types of PR were found to be at higher level in most of the tanks. The extent of alienation rights in most of the tanks was found to be low. The reason might be that the alienation rights for uses such as social forestry, duck rearing, brick making, silt collection, livestock grazing etc. were well defined but either not enforced properly by the formal/informal WUA (or) the very existence of these uses over tanks was reduced over the years. This had led to low level of alienation rights observed in most of the tanks.

It could be inferred that the extent of all the four types of PR except alienation right were specified and enforced in a better manner in most of the tanks. In more than onethird of the tanks, the bundle of PR over the tank resources was found to be at low level. Hence efforts are needed to strengthen the PR over the multi-uses of the tanks through strengthening the role and functioning of the WUA.

\section{Use-wise intensity of PR over the tank resources}

To understand the intensity of PR for each of the multiple uses of tanks, the use-wise PR scores were calculated for all the selected PU and WRO tanks separately. Based on the mean PR score for each use, the intensity of PR was calculated and categorized as low and high for that particular use. The frequency distribution of the tanks coming under each category was prepared and expressed in percentage. The results are presented in the Table 5. A cursory view of the table reveals that the intensity of PR was found to vary across the multiple uses of tank irrespective of the management authority of the tanks.

The overall analysis revealed that there were 11 uses observed in a tank system. It was understood that the intensity of PR in terms of access, withdrawal, management, exclusion and alienation, for the five uses of tank namely irrigation, social forestry, silt, fishing and bund trees were found to be exercised by various groups of users at lower levels of PR in most of the tanks. In these tanks, the PR was found to be enforced at a lower level by both the legal and customary rights. The uses namely domestic, duck rearing, hard grass rearing ('vizhal' in tamil language) collection, drinking and brick making uses were found to be enjoyed by the users at higher level of intensity of PR by the respective user group. Similar trend of results with regard to the use wise intensity of PR was observed for both PU and WRO tanks. However the PU tanks recorded low level of PR in all the tanks for the uses namely, domestic, LSG, LSD. In reality these three uses were not observed in recent years in all the selected PU tanks and hence the result.

Table 5 : Use-wise intensity of PR in Tanks

\begin{tabular}{|c|c|c|c|c|c|c|c|c|c|c|c|c|}
\hline \multirow[t]{3}{*}{ Uses } & \multicolumn{4}{|c|}{ PU tanks $(n=5)$} & \multicolumn{4}{|c|}{ WRO tanks $(n=26)$} & \multicolumn{4}{|c|}{ Total tanks $(n=31)$} \\
\hline & \multicolumn{2}{|c|}{ High } & \multicolumn{2}{|c|}{ Low } & \multicolumn{2}{|c|}{ High } & \multicolumn{2}{|c|}{ Low } & \multicolumn{2}{|c|}{ High } & \multicolumn{2}{|c|}{ Low } \\
\hline & $n$ & $\%$ & $\mathrm{n}$ & $\%$ & $\mathrm{n}$ & $\%$ & $n$ & $\%$ & $n$ & $\%$ & $n$ & $\%$ \\
\hline Irrigation & 2 & 40.00 & 3 & 60.00 & 10 & 38.46 & 16 & 61.54 & 12 & 38.71 & 19 & 61.29 \\
\hline Duck & 3 & 60.00 & 2 & 40.00 & 21 & 80.77 & 5 & 19.23 & 24 & 77.42 & 7 & 22.58 \\
\hline Brick & 2 & 40.00 & 3 & 60.00 & 14 & 53.85 & 12 & 46.15 & 16 & 51.61 & 15 & 48.39 \\
\hline Fishing & 3 & 60.00 & 2 & 40.00 & 5 & 19.23 & 21 & 80.77 & 7 & 22.58 & 24 & 77.42 \\
\hline Bund Trees & 2 & 40.00 & 3 & 60.00 & 11 & 42.31 & 15 & 57.69 & 14 & 45.16 & 17 & 54.84 \\
\hline Social Forestry & 1 & 20.00 & 4 & 80.00 & 11 & 42.31 & 15 & 57.69 & 15 & 48.39 & 16 & 51.61 \\
\hline Domestic use & 0 & 0.00 & 5 & 100.00 & 18 & 69.23 & 8 & 30.77 & 8 & 25.81 & 23 & 74.19 \\
\hline Desilting & 2 & 40.00 & 3 & 60.00 & 13 & 50.00 & 13 & 50.00 & 15 & 48.39 & 16 & 51.61 \\
\hline Vizhal (Hard grass rearing in tanks) & 0 & 0.00 & 5 & 100.00 & 15 & 57.69 & 11 & 42.31 & 11 & 35.48 & 20 & 64.52 \\
\hline Livestock Grazing & 0 & 0.00 & 5 & 100.00 & 9 & 34.62 & 17 & 65.38 & 17 & 54.84 & 14 & 45.16 \\
\hline
\end{tabular}


Common and reliable uses which are capable of generating relatively higher revenue were observed to possess the PR relatively at lower level as compared to uses that are complementary to common uses and which are relatively less (or) not capable of generating revenue from the respective users. In other words the intensity of PR seems to be high for those uses with less number of users (For eg. Domestic, collection of hard grass, duck rearing, LSG, LSD etc.) than for the uses like agriculture, fishery, SF, silt and bund trees wherein there were too many users with competition among them to enjoy the benefits of the resource.

It could be inferred that the level of PR may have been some influence on the level of collective efforts taken by the villagers either through formal or informal organizations. Such efforts or collective action might have several impacts on tank management. Hence existence of a strong users' institution would facilitate the users to enjoy the property rights over the tank resources at a higher level in an appropriate manner.

The claim over the benefits of a tank system was regulated among users by both legal and customary rights. Two popular customary norms namely (i) fixing limited area under tank irrigation for each farmer in the command area and (ii) fixing limited time of irrigation per acre of land owned by an individual farmer were followed to share water proportionate to the land area owned by the farmers in the tank command. In the case of fishery benefit it was through re-auctioning by the water users' association. The legal rights as defined by the state government laws governed the use of other non agricultural benefits and were enforced by various government departments. No rules existed to regulate the claim over domestic uses of the tank. Complete PR would facilitate the users to enjoy the benefit stream perfectly. Such condition was observed in $48.39 \%$ of the tanks only. Hence the PR over benefit streams of tank system needs to be strengthened in future through appropriate institutional arrangements. The intensity of PR in terms of access, withdrawal, management, exclusion and alienation, for the five uses of tank namely irrigation, social forestry, silt, fishing and bund trees were found to be exercised by various groups of users at lower level in most of the tanks. The uses namely domestic, duck rearing, hard grass collection, live stock drinking (LSD) and brick making were found to be enjoyed by the users at higher level of intensity of PR by the respective user group. Common and reliable uses which are capable of generating revenue were observed to possess the PR relatively at lower level as compared to uses that are complementary to common uses and which are relatively less (or) not capable of generating revenue from the respective users. In other words the intensity of PR seems to be high for those uses with less number of users than for the uses like agriculture, fishery, SF, silt and bund trees wherein there were too many users with competition among them to enjoy the benefits of the resource. Hence existence of a strong users institution would facilitate the users to enjoy the property rights over the tank resources at a higher level in an appropriate manner.
Empowering the WUA could be an innovation in the institutional arrangement to facilitate collective action of the tank users, intensify the property rights over the tank resources, reduce the competition and conflicts among users, evict the encroachments in the tank effectively, coordinate with various other institutions managing the tanks thereby promoting effective conservation of tank resources and sustainable management of tank irrigation system in South India.

\section{Case study on Kalpattu system tank}

Kalpattu is one of the system tank in villupuram district. The tank is located in Kaanai block of villupuram taluk and its command area extends from Kalpattu, Nathamedu and part of Siruvakoor villages irrigating 154-67-0 ha, 155-25-5 ha and 8942-5 ha, respectively. Source of supply channel from Sathanur via Pambaiyar channel. The over flow of the tank reaches upto south pennaiyar. This is an chain and mutlti village tank with 3 sluices the tank is kept under lock and key by the WUA in the Kalpattu village. Tank is located in the west to Kallpattu, Nathameduayacut in south and siruvakoor at the east end.

Water released from Sathanurannicut will reach the tank from Marudhur, Arcot, Ayandhur, and Kallpatuu. The over flow of Kalpatu goes to Mambalapattu, Malligaipattu, Kozhipatu then Kaanai, Paerumbakkam and finally ends in Thenpennaiyar. This tank is classified as II nd class tank since the water is supplied form the tank to ayacut is for a period of 9 months. Two fillings per year occur in the tank. Total population in the command area is 6252 with the male population of 3212 and female population of 3040. This tank has formal WUA and it was formed during 90's. Last WUA election was conducted during 2005. The formal WUA President is women Mrs. Baby w/o Kalveerayan, who completed her $8^{\text {th }}$ standard. But the acting WUA President is her husband who is also school teacher. All the caste people including OC, OBC and SC's are the members of the WUA. Total ayacutdars of this tank is 1104 and out of it, 353 members from the all three villages are the member of WUA. The others not enrolled their name but enjoying the irrigation and other benefits after formation of this institution. The command area comprising the different caste families Brahmins 35 families, Vanniyar 567 families, Udaiyar 532 families and high member of SC's ie 1550 families are dwelling. Out of them 27 families of Brahmin 312 Vanniyars, 282 Udaiyar families and $483 \mathrm{SC}$ had land in the tank ayacut.

Water released from Sathanuranicut takes 7 days to fill the tank when the anicut capacity is full due to the competition between the tanks ahead to the Kalpatu Those tank ayactudarars illegally tend to divert the water from the main channel to their own tanks or increase the shutter height by giving bribe to the Lascar of WRO.

During season (Rainy period) if normal rainfall occurs it will need only 2 days to fill the tank. Last 6 years there is no lascar appointment by the WRO to this tank due to lack of fund for the tank maintenance Hence the tank management was done locally by the informal and formal institutions of the tank and the ayacut villages 


\section{Tank management}

The traditional method of appointment of 'Thotti' from particular caste and family is followed in this tank even now also. 'Thottis' are the watchman for the tank and were usually appointed form SC community it is Kothu or Caste head based. In SC community, 40 years back how many families were lived in this village each of was called as one 'kothu' and now from each 'kothu' there might be many off springs and dwellings as individual families. But while appointing 'thotti' one person from one family, like wise 2 persons per year was appointed as 'thotti'. If all 'kothu's turn completed then other person of the $1^{\text {st }} \& 2^{\text {nd }}$ kothu is appointed as 'thotti'. So never repetition of the same person occurs. Their period is from January to December. Their duty is to open and close the sluice, to carry out if any small repairs in tank and to clean the supply channel as per the instructions of both the WUA of formal and the informal WUA president i.e Nattamai of the village.

For 'thotis' work, they were paid annually by the ayacutdars. Ayacutdaras who cultivated single/two crops of paddy should give 2 bundles of their harvested paddy which contained around 8 marakka ( 1 Marakka $=3.5 \mathrm{~kg}$ ) nearly $28 \mathrm{kgs}$ of paddy grains for 2 persons. But only $50 \%$ of the farmers (mostly who did 2 seasons of paddy cropping) in the tail and mid end gave their share correctly to the 'thotti'. Head end ayactudarars can easily get the water hence they will not be correctly paying their share to our thotti.

But for the past 8 years 'thotis' were looking after the supply channel and head structures when the water is relieved from the Sathanur dam, preventing illegal activities like diverting water by the ayacutdars of tank ahead, or increasing the shutter level of tank ahead or decrease the shutter level of Kalpatu. So the payment to 'thotti' was not regular. Since, they were not involved in water distribution to the individual fields.

'Kudimaramathu' or tank maintenance work was in practice, 25 years back in this tank. Most of the works for the tank maintenance was done 35 years back when the congress was ruling party in Tamil Nadu (Kamaraj period). But now poor maintenance of tank is observed due to the lack of fund allotment from Government to WRO for tank maintenance work, and this also gave rise to poor storage of water due to the encroachments in tank and supply channel. For the past 10 years no actions were taken by the WRO or Revenue Department for eviction of encroachments in the tank.

Kudimarathu is in practice for diverting water form the supply channel to the tank. Hence farmers who are all the ayacutdaras (mostly Head and middle end ayactudarars) pay ₹ 100 per acre by forming or deepening supply channels after getting Executive Engineers (WRO-Irrigation) permission to do so.

Regarding irrigation water sharing norms, 20 years back, head to tail end irrigation was followed. But now due to the lack of co-operation among farmers, who get the water from the tank can irrigate it and he does the water distribution to their field only. No preference given to any of the ayactudarars in water distribution. The first formation of formal WUA "Kalpattu Erineer Pasanavivasayigalsangam" was started during September 2005 by just accounting the entries of the members to get the benefit of the World Bank fund (matching grant) for the tank maintenance. But the purpose was not actually solved. No matching grant was allotted to this tank for maintenance work. When the members of the WUA struggled for it with the WRO they were not provided with the reply but they advised the WUA members that the formation of WUA is to maintain the tank by themselves. The tank had 4 Directors of WUA, i.e. 2 from Kalpattu each one from Nathamedu and Siruvakoor village. It was converted in to an elected body during 2004 and the President of WUA was given with five days training in Irrigation Management training centre at Thuvakudi and they were provided with the training and technical guidance which gave the procedures for the renewal registration of WUA and Management, Rules and regulation for Tamil Nadu tank irrigation and its management, soil and waters crop management in tank ayacut, lands, integrated water resource management role of women in tank management, tank management, and fish culture in tank system and its benefits were well explained .

Women involvement is as a labour at lower level and as a manager/administrator of agricultural inputs. But women never directly involved in irrigation activity. So, she stated that training participation and signing commitments alone were carried out by her. But apart from that for all the duties of WUA President were carried out informally by her husband Mr. Kalvarayan who is a higher secondary school teacher and farmer.

Hence he solved the problem or did tank management works along with the informal group which was already in the Kalpattu village (ayacut villages). The major tank irrigation maintenance problem solving and mobilization role was performed earlier by this informal group 30 years back. Now resource mobilization is only under its control. Fishing and bund tree auctions were the foremost resources apart from duck rearing, livestock grazing and drinking.

\section{Fishing}

Kalpattu tank was adopted by Department of Inland Fisheries and 10 years back this department released the fingerlings in the tank during water filling stage and harvest it after the water scarce period. But now due to inability of the Department to produce and release the fingerlings for the entire tank and unable to prevent the theft problems, it leased out the tank for fishery activity to the to the highest bidder.

Usually, as per the decision of informal group, any one of the IWUA member or a group claimed the auction (the auction amount is already fixed one) i.e. ₹ $1000 /-$ as EMD before bidding the auction. The highest amount of auction is ₹ 50,000/only. The date and time of auction was informed to the villagers through village administrative officer via thotti by tom-tom arrangement. The Inspector of fisheries accepted that the auction 
is said to be an open auction for name sake only. But to make it ease, avoiding the problems between the tank villagers and the auction bidders mostly auction rights were given to the local villager and highest bidder only. No fingerlings were released in the tank and once if the rights were handed over to the highest bidding person, there was no involvement of fishery department in the fish/tank management.

Once the formal and informal group has been divided to do the reauction no limitation for the participation. Any one can participate (mostly within the district) by paying ₹ $1000 /$ - as deposit which is refundable except for the highest bidder for whom it is detected from the auction amount. He should pay the full auction amount before the harvest and one half on the auction day itself. The highest bidding amount is up to ₹ 3.5 lakh and the highest bidder may get the profit up to ₹ 7.5 lakhs. The auction owned person himself released the fingerlings in the tank after the tank attained its FTL and no written agreement between water users and fishermen. But he should complete his fish harvest before the next filling and he was informed not to drain the water to harvest fish which would affect $2^{\text {nd }}$ season cropping of the ayacut farmers. After fish auction the tank is coming under the control of the auction owned person. He caught the fish and sold it in Kalpatu and nearby villagers and also to Villupuram town. Katla, rogu, mirgal are the fish varieties reared and viral is the local variety which lay eggs in the soil when water comes, it will hatch and multiply automatically. He is engaging nearly 6 persons-fisherman/day during harvest period @ the wage of ₹ 200/day. During rearing period of 10 months, three persons at the wage of ₹ 150 /day for supply of feed to the fish and prevent the illegal fishing.

The auction owned person is responsible either the benefit or loss faced in the fish rearing WUA/IWUA and he was not given any consideration in the forthcoming auction or repay the auction amount.

These fishery benefits shared among the local informal water users' group along with formal users' group into 50 shares, 3 villages viz., Kalpattu (W), Kalpatu (E) and Siruvakooray acutdaras on kothu basis they split the benefits. In Kalpattu (W) for Vanniyar 10 sharers, Udaiyar 10 shares for SC 10 shares; in Kallpattu (E) 10 shares and for Sirvakoor it is 10 shares. Since Kalpattu (W) is the tank village, caste wise sharing of the benefits was done where as nearby ayacut villages like Kalpatu (E) and Sirvakoor, the shares was given to the entire village. All the benefits earned out of this were utilized for the temple festival alone. In Kalpattu (W), the ayacutdars conducted the festival on the kothuor caste basis. Mari Amman temple festival during july-aug (Aadi) these fishing benefits "Macchamagasool" along with family cess (vari) ₹ 200/- family collected and 10 days festival conducted. 8 days festival cost is spent by tank villagers ie., Kalpatu (W) ayacutdaras and one day siruvakoor and one day by Nathamedu villagers The expenditure is maintained by IWUA along with WUA President acceptance during the end of the festival.
Bund trees which are not legally recorded in either WRO or Revenue department records were auctioned once in 5 years. The accounts were maintain by the Informal village group and this amount was utilized along with the 'macchamagasol' for conducting festival or spent for the village development works such as getting permission for higher secondary school to their village. It goes up to ₹ 6000/- for 5 years. For participating in the Bund tree auction, any one with ₹ 500/- deposit can so. Highest bidder in tree provided with the cutting rights. Auction conducted in the off-season, April-May when the tank water is at its BSL.

Duck rearing was done by leasing out the tank in May (15 years back) when the tank filling was at correct season. But now-adays, due to delayed monsoon, water when BSL and fish harvest time is delayed hence nowadays duck rearing is not allowed in the tank. 10 years past duck rearing was leased out by the village informal group head (Nattamai) and the auction amount was used for the festival purpose. The duration of duck rearing will not exceed 20 to 30 days and the amount for 500 ducks was ₹ 250 to 500 paid for leaving the ducks both in tank and tank ayacut land. Nearly ₹ 1,00,000/- per year both from local and near by villagers participated in the duck rearing in this tank.

But now, due to the delayed monsoon the water filling and water drain (BSL) stage is delayed. Hence fish harvest period is also delayed. So duck rearers were not allowed to leave their ducks in the tank. Sometimes based on the willingness of the ayacudarars they were allowed to leave their ducks in ayacut field. Sometimes it created 2 kinds of problem by duck rears:

1. Duckrearers informally release water illegally from tank which caused the problem to the fishermen and the person who is near field when he has not done the crop harvest. Then harvested paddy crop should be field dried for a few days when he decided to harvest by paddy harvester.

2. Duck rears who were allowed to leave their ducks in the paddy field when still some farmers prepared the land by puddling to take up rice planting, the land was damaged by the foot prints of the duck made in the field and it creates problem between the farmers and duck rearers.

Poor performance of tank and its water storage capacity is due to the lack of desilting and strengthening of bund, encroachment of supply channel and tank area. Formation of WUA is only on name sake and powers specified for WUA is not exercised or Government not enhance it as like panchayat president of the compulsory execution of powers in village Panchayat rules and powers are only in back and white unable to exercise it. Encroachments of supply channel and tank foreshore area were the major problems that affected the tank capacity. Supply channel encroachment by buildings of the Kaduvetti village people ahead of tank created problems between ayacutdars of Kalpattu and the encroachers of Kaduveti village.

Encroachments by the ayacutdaras in distributary channel in the head and mid end ayacut field made the tail end ayacut farmers 
poor or no supply of water even at full tank level/season. Hence problems created annually between head and tail end ayacutdars due to the encroachment in scarce period. At FTL floods occur and so unable to channelise water to the tail end both the mid and head ayactudarars are affected due to encroachment of distributary channel by the tail end farmers. The original width of supply channel was 40 links now reduced to 10 links due to the encroachment. Problem between fishermen and ayacutdaras are also noticed. Fishermen staked water to grow fish when the rainfall is scarce but the farmers wanted water and tends to pump out the water when he grows annual crop or second season paddy crop.

Informal groups indirectly supported or gave leniency in punishing the encroachers since they all belong to same village and also to avoid the local problem. No legal action was taken by the Informal groups on encroachers. Lack of funds or delay in allotment form Govt. department, procedural delay in getting Government assistance for tank maintenance, well defined rules which was not enforced actually were found to be the problems of the less effectiveness of the WUA performance in this tank.

Though the tank had the capacity to irrigate the ayacut area of 295.68.5 ha for $2^{\text {nd }}$ season which is a completely dry season with only one-fourth of the ayacut area now only 165.33.0 ha alone irrigated for $2^{\text {nd }}$ season due to the reasons mentioned above. Hence it is suggested by the members of WUA i.e. full powers just like panchayat president should be given to them for tank maintenance and resource mobilization only getting technical advice or assistance from Govt. department like WRO, Revenue and fishery department. Benefit sharing only with the ayacutdars and compulsory share on tank maintenance should be invested from tank resources would help the ayacutdars to maintain it and recoup it to an original form to feed the entire ayacut land.

\section{Acknowledgement}

The authors gratefully acknowledge the International Foundation for Science (IFS), Sweden for providing research grant (No. S/4334-1 dated $15^{\text {th }}$ August 2007) to the first author to carry out this study at the Tamil Nadu Agricultural University, Coimbatore, India. The efforts undertaken by Prof. Allan Curtis, Charles Sturt University, NSW, Australia to peer review the report of the IFS project is sincerely acknowledged.

\section{References}

FAO. 2005. Factors affecting the development and management of water resources for agriculture in the Lake Chad basin. FAOAGLW internal notes.

Food and Agricultural Organization (FAO), 2000. Application of the contingent valuation method in developing countries: a survey, Economic and Social Development Paper, p. 146.

Janakarajan S. 1996. Note on Irrigation Experience of Tamil Nadu. Proceedings of the Seminar on Conservation and Development of Tank Irrigation for Livelihood Promotion. Madurai: Conservation and Development Forum.

Meinzen-Dick, Ruth and Margaretha Bakker. 2000. Water Rights and Multiple Water Uses: Framework and Application to KirindiOya Irrigation System, Sri Lanka, EPTD Discussion Paper No. 59, IFPRI, Washington, DC.

Palanisami K, Balasubramanian R and Mohamed Ali A. 1997. Present, Status and Future Strategies of Tank Irrigation in Tamil Nadu. Bulletin 97, Water Technology Centre, Tamil Nadu Agricultural University Press, Coimbatore, India.

Raj ABS and Sundaresan D. 2005. Declining Trend in Tank-irrigated Area: Is There A Way To Arrest? Fourth IWMI-Tata Annual Partners Meet. Anand, February.

Schlager E and Ostrom E. 1992. Property rights regimes and natural resources: A conceptual analysis, land economics, 68(3): 249-62.

Singh Katar. 1994. Managing Common Pool Irrigation Tanks: A Case Study, in Katar Singh (Eds.) Managing Common Pool Resources : Principles, Policies and Management, New Delhi : Sage Publications.

Tiwari DN. 1998. Determining economic value of irrigation water: comparison of willingness to pay and indirect valuation approaches as a measure of sustainable resource use.

World Bank. 1993. Water Resources Management: A Policy Paper. The World Bank, Washington D.C. 